\title{
Volatility spillovers in EMU sovereign bond markets
}

\author{
Fernando Fernández-Rodríguez ${ }^{\mathrm{a}}$, Marta Gómez-Puig and Simón Sosvilla-Rivero ${ }^{\mathrm{c}}{ }^{\mathrm{b}}$ \\ ${ }^{a}$ Department of Quantitative Methods in Economics, Universidad de Las Palmas de Gran \\ Canaria, 35017 Las Palmas de Gran Canaria, Spain \\ ${ }^{b}$ Department of Economic Theory, Universitat de Barcelona. 08034 Barcelona, Spain \\ 'Complutense Institute for International Studies, Universidad Complutense de Madrid. \\ 28223 Madrid, Spain
}

Revised version, July 2015

\begin{abstract}
New evidence is presented on the sudden shift in the sentiment of market participants with the outbreak of the sovereign debt crisis. Since volatility reflects the extent to which the market evaluates the arrival of new information and provides useful insights into the dynamics of EMU sovereign debt markets, we analyse their spillovers. To that end, we first examine the unconditional patterns during the full sample (April 1999-January 2014) using a measure recently proposed by Diebold and Yilmaz (2012). Second, we make use of a dynamic analysis to evaluate net directional volatility spillovers for each of the eleven countries under study, and to determine whether core and peripheral markets present differences both before and during the crisis periods. Finally, we apply a panel analysis to empirically investigate the determinants of net directional spillovers of this kind. Our results suggest that slightly more than half of the total variance of the forecast errors is explained by shocks across countries rather than by idiosyncratic shocks. Besides, they give further support to the idea that during the pre-crisis period, most of the triggers in the volatility spillovers were central countries -peripheral countries imported credibility from them- while during the crisis peripheral countries became the dominant transmitters.
\end{abstract}

Keywords: Sovereign debt crisis, Euro area, Market Linkages, Vector Autoregression, Variance Decomposition.

JEL Classification Codes: C53, E44, F36, G15

\footnotetext{
${ }^{*}$ Corresponding author. Tel.: +34 934020113; fax: +34 934039082.

E-mail addresses: fernando.fernandez@ulpgc.es (F. Fernández-Rodríguez), marta.gomezpuig@ub.edu (M. Gómez-Puig), sosvilla@,ccee.ucm.es (S. Sosvilla-Rivero)
} 


\section{Introduction}

Recent financial crises have all been characterized by quick, large-scale regional spillovers of negative financial shocks. These have been especially significant in Europe where, after the huge distress in the Greek government debt market that culminated in the rescue of May 2010, South European countries found their yield spreads with respect to Germany spiralling, and also faced skyrocketing refinancing rates. Indeed, an important reason and justification for providing financial support to Greece was precisely the "fear" of contagion (see Constâncio, 2012); there was a sudden loss in investor confidence and the macroeconomic and fiscal imbalances within the rest of EMU countries came firmly under the spotlight (see Beirne and Fratzscher, 2013).

The significant increase in cross-border financial activity in the euro area since the start of the century (see Kalemli-Ozcan et al., 2010 and Barnes et al., 2010), which has fostered a high degree of integration in European financial markets ${ }^{1}$, and the low degree of fiscal federalism are some of the reasons for the speed, as well as the amplitude, of the transmission of those shocks. Clearly, empirical studies are needed to evaluate the importance of spillovers across public debt markets.

Researchers have already used a variety of methodologies to study the transmission effects in euro area sovereign debt markets (correlation-based measures, conditional value-at-risk or Granger-causality approach, among others) ${ }^{2}$ : Kalbaska and Gatkowski (2012), Metiu (2012), Caporin et al. (2013), Beirne and Fratzscher (2013), Gorea and Radev (2014), Gómez-Puig and Sosvilla-Rivero (2014) and Ludwig (2014) to name a few. Our paper adds to this literature by applying the methodology recently proposed by Diebold and Yilmaz (2012) to measure spillover effects using a generalized vector autoregressive framework in

1 See Schoenmaker and Wagner (2013)

${ }^{2}$ See Biblio et al. (2012) for a review of the different measures proposed in the literature to estimate these linkages. 
which forecast-error variance decompositions are invariant to the variable ordering. This methodology allows us to examine the relative importance of both within-market and cross-market information in explaining volatility movements in each EMU sovereign bond market. Besides, it also allows us: (1) To evaluate total spillovers of volatility across these markets; (2) To compute net directional volatility spillovers summarizing information about how much each market contributes to the volatility in other markets, in net terms; (3) To produce continuously-varying indexes of total and net directional spillovers illustrating how markets evolved over time and reacted to the impressive number of specific events that took place during the sample; and (4) To map out the complex network of volatility interlinkages among the eleven markets in our sample.

Besides, to our knowledge, although there is a substantial body of literature using different extensions of Diebold and Yilmaz (2012)'s methodology to examine spillovers and transmission effects in stock, foreign exchange, or oil markets in non-EMU countries $^{3}$, it has only rarely been applied to euro area sovereign debt markets (Antonakakis and Vergos, 2013, Claeys and Vašicek, 2014 and Glover and Richards-Shubik, 2014 are some of the few exceptions $)^{4}$. Nevertheless, in contrast to those studies, we focus our analysis on sovereign debt market volatility, since as far as we know; there are no empirical analyses of the effects of spillovers on sovereign market volatility, in spite of the relevance of the issue.

In this sense, as volatility reflects the extent to which the market evaluates and assimilates the arrival of new information, the analysis of its transmission pattern might provide useful insights into the characteristics and dynamics of sovereign debt markets. So, since the information gathered would provide a barometer for the vulnerability of these markets, we

\footnotetext{
3 Awartania et al., (2013), Lee and Chang (2013), Chau and Deesomsak (2014) or Cronin (2014) apply this methodology to examine spillovers in the United States markets; Yilmaz (2010), Zhou et al. (2012) or Narayan et al. (2014) focus their analysis on Asian countries; Apostolakisa and Papadopoulos (2014) and Tsai (2014) examine G-7 economies; whilst Duncan and Kabundi (2013) center their analysis on South African markets.

4 Alter and Beyer (2014) also apply this methodology to quantify spillovers between sovereign credit markets and banks in the euro area.
} 
consider that to empirically examine spillovers on sovereign debt market volatility is a novel and relevant issue. Moreover, during crises, markets' volatilities tend to increase rapidly, and financial analysts seem to believe that volatility shocks in one market can easily have an impact on the other markets. Thus, the European debt crisis is ideal for testing net directional spillovers, identifying when and where they started in sovereign bond markets and how subsequently spread to the rest of countries.

Therefore, the main objective of this paper is to contribute to this challenging avenue of research by focusing on the effects of spillovers on EMU sovereign bond market volatility. Unlike previous studies, in our analysis we will focus on euro area countries; though we consider both central (Austria, Belgium, Finland, France, Germany and the Netherlands) and peripheral EMU countries (Greece, Ireland, Italy, Portugal and Spain) ${ }^{5}$ and work with 10-year yields instead of spreads over the German bund, in order to be able to include Germany in the study. Furthermore, whilst other studies analyse bond yield spread spillovers (Antonankakis and Vergos, 2013, among them), we will study bond yields' volatility spillovers. We will analyse the determinants of the detected pair-wise net directional spillovers, considering not only macroeconomic fundamentals, but also the role played by indicators of investor sentiment. Finally, we examine an extended time period spanning from the inception of the euro in January 1999, well before the global financial and sovereign debt crises, until January 2014, covering the Greek write-off and the agreement with Greece's creditor banks in 2012 and the decision of Eurogroup to consider bail-ins in the future, that was eventually decided in 2013, after the crisis in Cyprus.

\footnotetext{
5 This distinction between central and peripheral countries has been extensively used in the empirical literature. The two groups we consider roughly correspond to the distinction made by the European Commission (1995) between those countries whose currencies continuously participated in the European Exchange Rate Mechanism (ERM) from its inception maintaining broadly stable bilateral exchange rates among themselves over the sample period, and those countries whose currencies either entered the ERM later or suspended its participation in the ERM, as well as fluctuating in value to a great extent relative to the Deutschmark. These two groups are also roughly the same found in Jacquemin and Sapir (1996), applying multivariate analysis techniques to a wide set of structural and macroeconomic indicators, to form a homogeneous group of countries. Moreover, these two groups are basically the same that those found in Ledesma-Rodríguez et al. (2005) according to the perception of economic agents with respect to the commitment to maintain the exchange rate around a central parity in the ERM and those identifying by Sosvilla-Rivero and MoralesZumaquero (2012) using cluster analysis when analysing permanent and transitory volatilities of EMU sovereign yields.
} 
Our results suggest that a little more than half of the total variance of the forecast errors is explained by shocks across countries rather than by idiosyncratic shocks. Besides, they give further support to the idea that during the pre-crisis period, most of the triggers in the volatility spillovers were central countries - peripheral countries imported credibility from them- while during the crisis peripheral countries became the dominant transmitters. These results are in line with those of Antonakakis and Vergos (2013) who also highlight the increased vulnerability of EMU countries from the destabilizing shocks originating from the beleaguered peripheral countries rather than from core countries during the crisis.

We proceed as follows. In section 2 we discuss the econometric methodology. Section 3 describes our data and presents our empirical results (both static and dynamic). In Section 4 we present the empirical results regarding the pair-wise net directional spillovers and examine their determinants. Finally, Section 5 summarizes the main findings and offers some concluding remarks.

\section{Econometric methodology}

We use the method developed by Diebold and Yilmaz (2012). The starting point of the analysis is the following $p$-order, $N$-variable Vector Autoregressive (VAR) model:

$$
x_{t}=\sum_{i=1}^{p} \Phi_{i} x_{t-i}+\varepsilon_{t}
$$

where $\varepsilon_{t} \sim \operatorname{iid}(0, \Sigma)$ is a vector of independently and identically distributed errors.

The key to the dynamics of the system is the moving average representation of model (1), which is given by

$$
x_{t}=\sum_{i=1}^{\infty} A_{i} \varepsilon_{t-i}
$$


where the $N \times N$ coefficient matrices $A_{i}$ are estimated by the recursion $A_{i}=\Phi_{1} A_{i-1}+\Phi_{2} A_{i-2}+\ldots+\Phi_{p} A_{i-p}$, with $A_{0}$ being an $N \times N$ identity matrix and with $A_{i}=0$ for $i<0$. Diebold and Yilmaz (2012) use the generalized VAR framework of Koop et al. (1996) and Pesaran and Shin (1998), in which variance decompositions are invariant in terms of the variable ordering. In this case, the $H$-step-ahead forecast error variance decomposition is defined as follows:

$$
\theta_{i j}^{g}(H)=\frac{\sigma_{j j}^{-1} \sum_{h=0}^{H-1}\left(e_{i}^{\prime} A_{h} \Sigma e_{j}\right)^{2}}{\sum_{h=0}^{H-1}\left(e_{i}^{\prime} A_{h} \Sigma A_{h}^{\prime} e_{j}\right)},
$$

where $\Sigma$ is the variance matrix for the error vector $\varepsilon, \sigma_{j j}$ is the standard deviation of the error term for the $j$ th equation, and $e_{i}$ is the selection vector, with one as the $i t h$ element and zeros otherwise.

In the generalized VAR framework, the shocks to each variable are not orthogonalized; therefore, the sum of each row of the variance decomposition matrix does not add to unity $\left(\sum_{j=1}^{N} \theta_{i j}^{g}(H) \neq 1\right)$. In this case, each element of the decomposition matrix is normalized by dividing it by the row sum:

$$
\tilde{\theta}_{i j}^{g}(H)=\frac{\theta_{i j}^{g}(H)}{\sum_{j=1}^{N} \theta_{i j}^{g}(H)},
$$

where, by construction, $\sum_{j=1}^{N} \tilde{\theta}_{i j}^{g}(H)=1$ and $\sum_{i, j=1}^{N} \tilde{\theta}_{i j}^{g}(H)=N$. 
Using the normalized elements of the decomposition matrix of equation (4), we construct the total volatility spillover index:

$$
S^{g}(H)=\frac{\sum_{\substack{i, j=1 \\ i \neq j}}^{N} \tilde{\theta}_{i j}^{g}(H)}{\sum_{i, j=1}^{N} \tilde{\theta}_{i j}^{g}(H)} \cdot 100=\frac{\sum_{\substack{i, j=1 \\ i \neq j}}^{N} \tilde{\theta}_{i j}^{g}(H)}{N} \cdot 100 .
$$

This index captures the level of cross-country spillovers by measuring the contribution of the spillovers of volatility across all countries to the total forecast error variance. To examine the spillover effects from and toward a specific country, we use directional volatility spillovers. Specifically, the directional volatility spillovers received by market $i$ from all other markets $j$ are defined as follows:

$$
S_{i .}^{g}(H)=\frac{\sum_{\substack{j=1 \\ i \neq j}}^{N} \tilde{\theta}_{i j}^{g}(H)}{\sum_{i, j=1}^{N} \tilde{\theta}_{i j}^{g}(H)} \cdot 100=\frac{\sum_{\substack{j=1 \\ i \neq j}}^{N} \tilde{\theta}_{i j}^{g}(H)}{N} \cdot 100
$$

In a similar fashion, the directional volatility spillovers transmitted by market $i$ to all other markets $j$ are defined as follows:

$$
S_{i \cdot}^{g}(H)=\frac{\sum_{\substack{j=1 \\ i \neq j}}^{N} \tilde{\theta}_{j i}^{g}(H)}{\sum_{i, j=1}^{N} \tilde{\theta}_{j i}^{g}(H)} \cdot 100=\frac{\sum_{\substack{j=1 \\ i \neq j}}^{N} \tilde{\theta}_{j i}^{g}(H)}{N} \cdot 100 .
$$

The net directional volatility spillover provides information on whether a market is a receiver or a transmitter of volatility in net terms. We obtain the net spillover from market $i$ to all other markets $j$ by subtracting equation (7) from equation (6). Thus, the net directional volatility spillover is given by the following: 


$$
S_{i}^{g}(H)=S_{\cdot i}^{g}(H)-S_{i \cdot}^{g}(H)
$$

To examine the net pairwise volatility spillover between markets $i$ and $j$, we compute the difference between the gross volatility shocks transmitted from market $i$ to market $j$ and those transmitted from $j$ to $i$ :

$$
S_{i j}^{g}(H)=\left(\frac{\tilde{\theta}_{j i}^{g}(H)}{\sum_{i, k=1}^{N} \tilde{\theta}_{i k}^{g}(H)}-\frac{\tilde{\theta}_{i j}^{g}(H)}{\sum_{j, k=1}^{N} \tilde{\theta}_{j k}^{g}(H)}\right) \cdot 100=\left(\frac{\tilde{\theta}_{j i}^{g}(H)-\tilde{\theta}_{i j}^{g}(H)}{N}\right) \cdot 100
$$

\section{Data and empirical results}

\subsection{Data}

We use daily data of 10 -year bond yield from data collected from Thomson Reuters Datastream for eleven EMU countries: both central (Austria, Belgium, Finland, France, Germany and the Netherlands) and peripheral countries (Greece, Ireland, Italy, Portugal and Spain). Our sample begins on 1 April 1999 and ends on 27 January 2014 (i. e., a total of 3,868 observations) $)^{6}$, spanning several important financial market episodes in addition to the crisis of 2007-2008 - in particular, the euro area sovereign debt crisis from 2009 onwards. Following Parkinson (1980), we estimate the daily variance using daily high and low prices ${ }^{7}$. For market $i$ on day $t$ we have

$$
\tilde{\sigma}_{i t}^{2}=0.36\left[\ln \left(P_{i t}^{M A X}\right)-\ln \left(P_{i t}^{M I N}\right)\right]^{2} .
$$

where $P_{i t}^{M A X}$ it is the maximum (high) price in market $I$ on day $t$, and $P_{i t}^{M I N}$ is the daily minimum (low) price. Given that $\tilde{\sigma}_{i t}^{2}$ is an estimator of the daily variance, the

\footnotetext{
${ }^{6}$ The sample starts in April 1999 since data for Greece are only available from that date.

7 We also used the absolute standardized log-return and the squared returns as alternative measures of daily volatility, being the results qualitatively similar.
} 
corresponding estimate of the annualized daily percent standard deviation (volatility) is $\hat{\sigma}_{i t}^{2}=100 \sqrt{365 \tilde{\sigma}_{i t}^{2}}$

\subsection{Total spillovers}

Table 1 displays the total volatility spillovers computed for the whole sample. The offdiagonal column sums (labelled "Contributions to others") or row sums (labelled "Contributions from others"), are the "to" and "from" directional spillovers, and the "from minus to" differences are the net volatility spillovers. In addition, the total volatility spillover index appears in the lower right corner of the spillover table. It is approximately the grand off-diagonal column sum (or row sum) relative to the grand column sum including diagonals (or row sum including diagonals), expressed as a percentage. As can be seen, we obtain a value of $54.23 \%$ for the total volatility spillover index among the eleven countries under study, indicating that slightly more than half of the total variance of the forecast errors during the sample is explained by shocks across countries, whereas the remaining $45.77 \%$ is explained by idiosyncratic shocks.

\section{[Insert Table 1 here]}

Regarding pairwise directional spillovers (the off-diagonal elements of the upper-left $11 \times$ 11 submatrix), the highest observed pairwise volatility spillover is from Italy to Spain $(34.03 \%)$. In return, the pairwise volatility spillover from Spain to Italy $(25.27 \%)$ is secondhighest. The highest pairwise spillover value between EMU central countries is from France to Austria (20.03\%), followed by that from France to the Netherlands (18.85\%).

In terms of the directional spillovers to others throughout the full sample, our results suggest that volatility in Finnish bond yields contributed the most to other countries' forecast error variance (78.58 points), followed by Dutch bond yields (78.24 points), 
French bond yields (74.83 points), Austrian bond yields (74.15 points) and German bond yields (71.23 points). According to the full sample volatility spillover measures, Belgium, Italy and Spain occupy intermediate positions (62.02, 53.63 and 48.99 points respectively), while Ireland, Greece and Portugal contributed similar rates $(16.48,13.69$ and 13.17 points respectively).

As for the directional spillovers received from others, Germany appears to be the country that received the highest percentage of shocks from other countries (79.95) followed by Finland (79.61 points) and the Netherlands (79.36 points). Greece received the lowest percentage (7.34 points) of shocks from other countries, followed by Ireland (28.82 points) and Italy (32 points).

Finally, we calculate the difference between the column-wise sum (the "Contribution to others") and the row-wise sum ("Contribution from others") to obtain the "net directional volatility spillovers". Italy (21.63 points) and Spain (10.68 points) are net transmitters of bond yield shocks to other countries, while Austria (-2.02 points), the Netherlands (-1.12 points) and Finland (-1.03 points) received very low percentage of bond yield shocks in net terms. On the other hand, Portugal (-32.37 points) and Ireland (-12.34 points) are definitely the leading net receivers of bond yield shocks over the full period. These results are in line with those presented in Suh (2015) applying new measures of contagion effects during the recent Eurozone sovereign debt crisis.

To gain further insights into the dynamics of the total volatility spillovers, we now estimate them using a $\operatorname{VAR}(2)$ approximating model with a one-sided rolling estimation window of 200 days $^{8}$ and 10 days as the predictive horizon for the underlying variance decomposition, and assess the extent and nature of spillover variation over time via the corresponding time

${ }_{8}^{8}$ Following Inoue, Jin and Rossi (2014), we choose the optimal window size that minimizes the conditional mean square forecast errors. This procedure is found to perform quite well under various types of structural changes. 
series of spillover indexes, which we examine graphically in the total spillover plot in Figure 1.

[Insert Figure 1 here]

As can be seen in Figure 1, we identify two periods ${ }^{9}$, being April 62009 the breakpoint. Therefore, during the first period (from April 11999 to April 5 2009), which is denoted as the pre-crisis period, yield volatility was substantially transmitted to others (we should recall that, in this period, euro sovereign bond markets were highly connected and yield spreads moved in a narrow range close to zero); while in the second one (from April 62009 till the end of the sample period), denoted crisis period, in parallel with the disconnection in sovereign markets behaviour (yield spreads against the German bund spiralled), the spillover of bond yield volatility registered a decrease. The breakpoint (April 6 2009) coincides with a statement by the ECB expressing its fears of slowdown in financial market integration, and only some months before Papandreou's government reported Greece's distressed debt position (November 2009) ${ }^{10}$.

\section{Net pairwise directional volatility spillovers}

We now focus on the net directional spillover plots to explore the time-varying differences between directional TO and directional FROM spillovers (i.e., 'TO-FROM') for our eleven sovereign yields. In particular, we examined the 110 net pair-wise directional volatility spillovers. The resulting figures (not shown here to save space, but available from the

\footnotetext{
${ }^{9}$ Formal mean and volatility tests (not shown here to save space, but available from the authors upon request) strongly reject the null hypothesis of equality in mean and variance before and after April 6 2009, suggesting the existence of two regimes.

10 In November 2009, Papandreou's government disclosed that its finances were far worse than previously announced, with a yearly deficit of $12.7 \%$ of GDP, four times more than the euro area's limit (and more than double the previously published figure), and a public debt of $\$ 410$ billion. We should recall that this announcement only served to worsen the severe crisis in the Greek economy; the country's debt rating was lowered to BBB+ (the lowest in the euro zone) on December 8. These episodes marked the beginning of the euro area sovereign debt crisis.
} 
authors upon request $)^{11}$ indicate that during the period under study Greece, Ireland and Portugal were the dominant net transmitters of sovereign bond volatility, while Austria, Belgium, Finland, France, Germany, Italy, The Netherlands and Spain, were mostly on the receiving end of net volatility transmission. Additionally, the results also reveal that net directional volatility spillovers vary greatly over time.

Figures $2 \mathrm{a}$ to $2 \mathrm{c}$ synthetically display the main results for our dynamic analysis of net pairwise directional spillovers, focusing on cases where the intensity was especially significant. In the Figures, we provide a visualization of the complex network of volatility overflows among the eleven sovereign bond markets in our sample. The width of the arrows indicates the intensity of volatility spillovers and the node diameter indicates sovereign debt market size. Specifically, Figure 2a shows the most significant net pair-wise directional spillovers for the whole sample, whilst Figure $2 \mathrm{~b}$ and $2 \mathrm{c}$ present the main results obtained during the pre-crisis and crisis periods respectively ${ }^{12}$.

[Figures 2a to 2c here]

As can be seen, for the whole sample (Figure 2a) in ten out of the fourteen main cases the triggers in the volatility spillovers are peripheral countries (the receivers being central countries in six cases and peripheral countries in four), while in the remaining four cases central countries represent the origin and destiny of the volatility spillovers. It can also be seen in Figure $2 \mathrm{~b}$ that during the pre-crisis period, in 23 out of the 26 relevant cases the dominant triggers in the volatility spillovers are central countries (the receivers being peripheral countries in fourteen cases and central countries only in nine), while peripheral countries are the origin of the volatility spillovers in only three cases (the destination being

${ }^{11}$ However, a subset that encompasses the most important patterns found in the pre-crisis and crisis period is presented in Figures $3 \mathrm{a}$ and $3 \mathrm{~b}$.

12 Figures $2 \mathrm{a}$ to $2 \mathrm{c}$ only show the most important directional connections between the 55 pairs of the 10 -year bond yields under study which correspond to the cases where we detect a net pair-wise directional connection in $64-75 \%, 76-87 \%$ and $88-100 \%$ of the sample. They account for a total of 14 connections when we study the whole sample (Figure $2 \mathrm{a}$ ), 26 in the pre-crisis period (Figure $2 \mathrm{~b}$ ) and 42 in the crisis period (Figure 2c). 
a peripheral country in all three). Finally, Figure 2c suggest that, during the crisis period, the pattern of major net pair-wise directional spillovers radically changes, both in intensity (the amount detected in the tenth percentile represents $71 \%$ of the total, whilst we detected no spillovers in that percentile in the pre-crisis period) and in direction: in 35 out of the 42 cases the main triggers in the volatility spillovers are peripheral countries (the receivers being central countries in 29 cases and peripheral countries in six), while only in seven cases are central countries the origin (and destination) of the volatility spillovers.

Taken together, the evidence thus far suggests that there are important episodes of volatility spillovers across EMU sovereign bond markets and that, as the crisis intensified, so too did the volatility spillovers with a significant change in the spillover direction. Therefore, these results could reinforce the idea that during the first ten years of currency union, investors overestimated the healing effect that "sound" central countries might have on the rest of the Eurozone, and spillovers ran mostly from central to peripheral countries (accounting for $54 \%$ of the total; fourteen cases out of twenty six). However, with the onset of the crisis the situation changed radically: suddenly, market participants focused their attention on the major macroeconomic imbalances in some peripheral countries, which might not only lead them to default, but might also affect the central countries which held a substantial proportion of their sovereign assets Therefore, in the crisis period, not only the number and the intensity of volatility spillovers increased but their direction as well, now running mostly from peripheral to central countries (they account for $69 \%$ of the total; twenty nine cases out of forty two). The detailed time-varying behaviour of net pairwise spillovers between these subsets of countries is presented in Figure $3 \mathrm{a}$ and Figure 3b. Concretely, Figure $3 \mathrm{a}$ displays the main net spillovers in the precrisis period (i.e., 14 relationships running from central to peripheral countries), whilst 
Figure $3 \mathrm{~b}$ shows the main net spillovers in the crisis one (i.e., 29 relationships running from peripheral to central countries).

[Insert Figures 3a and 3b here]

Figures $3 \mathrm{a}$ and $3 \mathrm{~b}$ complement the information presented in Figures $2 \mathrm{a}$ to $2 \mathrm{c}$; they show not just the change in the spillovers' direction with the crisis, but also the huge increase in their number and intensity.

\subsection{Determinants of net pairwise directional volatility spillovers}

\subsubsection{Econometric methodology}

After evaluating net pairwise directional volatility spillovers, we proceed now to analyse their determinants. We adopt an agnostic data-driven approach, using a general-to-specific modelling strategy with panel data techniques, to empirically assess the relevance of the variables proposed in the recent theoretical and empirical literature as potential drivers of EMU sovereign bond yield spreads in explaining the net pairwise volatility spillovers we have calculated.

Since the potential determinants are available at monthly or quarterly frequency, we generate a new dependent variable computing the monthly average of the daily net pairwise directional volatility spillovers for each country.

\subsubsection{Instruments for modelling net pairwise directional volatility spillovers}

Following Dornbusch et al. (2000), we distinguish between two types of potential reasons for the evolution of net pairwise directional volatility spillovers: fundamentals-based variables and investor behaviour-based determinants. 
As far as the macro-fundamentals are concerned, in accordance with the literature, we include measures of the country's fiscal position (the government debt-to-GDP and the government deficit-to-GDP, DEB and DEF hereafter), the liquidity differences between markets (the overall outstanding volume of sovereign debt, LIQ) ${ }^{13}$, the foreign debt and net position of the country towards the rest of the world (the current-account-balance-to-GDP ratio, $\mathrm{CAC}$ ) and a measure of inflation as a proxy of the country's loss of competitiveness (the Harmonized Index of Consumer Prices monthly inter-annual rate of growth, INF). These variables have been widely used in the empirical literature as potential drivers of both sovereign yields and sovereign default (see, e. g., Gómez-Puig et al., 2014 and Chakrabarti and Zeaiter, 2014). With respect to market sentiment proxies, we use the consumer confidence indicator (CCI) to gauge economic agents' perceptions of future economic activity and the monthly standard deviation of equity returns (EVOL) in each country to capture local stock market volatility. All this variables are in relative terms and represent the difference between their values in the two countries involved in the net directional bond yield volatility spillovers. Since we have detected (see Figure 1) that in periods of sovereign debt markets stability, total volatility spillover is much higher than in periods of distress in public debt markets, we expect that the instrumental variables impact on net directional volatility spillovers presents the opposite sign that the one they had on yield spreads. Therefore, we would expect a positive relationship between the variables CAC, LIQ and CCI with net directional volatility spillovers; and a negative relationship for the variables DEB, DEF, INF and EVOL (see Gómez-Puig et al., 2014).

\footnotetext{
13 Given the large size differences observed between EMU peripheral sovereign debt markets (see Gómez-Puig and Sosvilla-Rivero, 2013), it is likely that the overall outstanding volume of sovereign debt (which is considered a measure of market depth because larger markets may present lower information costs since their securities are likely to trade frequently, and a relatively large number of investors may own or may have analysed their features) might be a good proxy of liquidity differences between markets. Indeed, some of the literature indicates the importance of market size in the success of a debt market.
} 
A summary with the definitions and sources of all the explanatory variables used is presented in Appendix A.

\subsubsection{Empirical results}

As mentioned above, we start our eclectic empirical analysis with a general unrestricted statistical model including all explanatory variables that might influence the variables being modelled, which in our case are net pairwise directional volatility spillovers. Using standard testing procedures, we search down to the smallest model with the greatest explanatory power, based on sequences of $t$ tests and F-tests to check the validity of the reductions at each stage in order to ensure the congruence of the finally selected model (Hendry, 1995, ch. 9).

The first column in Tables 2 to 5 shows the final estimation results during the whole sample period for net pairwise volatility spillovers between four groups of countries: (1) all EMU countries, (2) EMU central countries, (3) EMU peripheral countries and (4) between EMU central and peripheral countries. The results in the second column of these tables take into account the dynamic properties of the explanatory variables by introducing a dummy to analyse the differences in the coefficients' significance over time (i.e., during the stability and the crisis periods).

Therefore, in addition to the chosen independent variables, a dummy (DCRISIS, taking the value 1 in the crisis period and 0 otherwise) is also introduced in the estimations and the coefficients of the interactions between this dummy and the rest of variables are calculated $^{14}$ :

$\beta=\beta_{1}+\beta_{2}$ DCRISIS

${ }^{14}$ See Gómez-Puig (2006 and 2008) 
Then, the marginal effects of each variable are:

$\beta=\beta_{1}$ (in the stability period)

$\beta=\beta_{1}+\beta_{2}$ (in the crisis period)

All the results reported in Tables 2 to 5 were obtained using the Fixed Effects (FE) model which is the relevant model in all cases ${ }^{15}$.

[Insert Tables 2 to 5 here]

Looking across the columns in these tables, and examining the spillovers between all eleven countries (Table 2) and only between central and peripheral countries (Table 5) some common patterns can be observed. With regard to the variables measuring market sentiment, we find a negative, significant effect for stock-market volatility (EVOL), whereas, as expected, the consumer confidence indicator (CCI) presents a positive sign. As for the local macro-fundamentals, our results suggest a negative impact on net directional spillovers of one variable that measures the fiscal position (the government debt-to-GDP) and another one that gauges the country's level of competitiveness (INF) ${ }^{16}$. Moreover, without exception, all marginal effects register an increase in the crisis period compared to the pre-crisis period. This rise in the sensitivity to both fundamentals and market sentiments during the crisis period compared with the pre-crisis period is in line with the previous empirical literature (see Gómez-Puig et al., 2014, among others). The reassessment of objectively unchanged fundamentals in other countries, when a crisis occurs in one country is what Goldstein (1998) calls 'wake-up call' contagion, since it draws the attention

\footnotetext{
15 We consider three basic panel regression methods: the fixed-effects (FE) method, the random effects (RE) model and the pooled-OLS method. In order to determine the empirical relevance of each of the potential methods for our panel data, we use several statistic tests. Specifically, we test FE versus RE using the Hausman test statistic to test for noncorrelation between the unobserved effect and the regressors. To choose between pooled-OLS and RE, we use Breuch and Pagan (1980)'s Lagrange multiplier test to test for the presence of an unobserved effect. Finally, we use the F test for fixed effects to test whether all unobservable individual effects are zero, in order to discriminate between pooled-OLS and RE. To save space, we do not show these tests here, but they are available from the authors upon request.

${ }_{16}$ Besides, our proxy for the market liquidity also turns out to be significant in the estimations of the spillovers within central and peripheral countries (Table 5).
} 
of market participants to existing problems or risks they failed to see beforehand, and so is the result of an efficient correction that leads to a more accurate assessment of fundamentals.

It is worth noting that our analysis highlights the differences between the two groups of EMU countries: central and peripheral. In net directional spillover episodes between central countries (see Table 3), variables that gauge macroeconomic fundamentals seem to present a relatively higher relevance, while participants' perceptions seem to play a major role in relationships between peripheral countries (see Table 4). In both cases, four variables assessing macroeconomic fundamentals are significant with the expected sign.

However, while only one variable measuring market sentiment (the consumer confidence indicator, CCI) is statistically significant to explain spillovers between central countries, two variables (EVOL and CCI) are significant with the expected sign in the case of peripheral countries. Again, without exception, for the two groups of countries all marginal effects register an increase in the crisis period compared to the pre-crisis period.

Therefore, our results indicate that the crisis had a significant impact on the markets' reactions to financial news, especially in EMU peripheral countries. In this respect, some authors have argued that a financial crisis might spread from one country to another due to market imperfection or to the herding behaviour of international investors. For instance, Beirne and Fratscher (2013) also indicate that for EMU peripheral countries there is strong evidence in favour of this hypothesis, though for other countries the evidence is much weaker since macroeconomic fundamentals are more relevant. Moreover, the time-varying impact of the different variables in the crisis and pre-crisis periods is another interesting finding that supports the idea that, when a shock occurs, market participants reconsider the effects of relevant variables. 


\section{Concluding remarks}

The recent crisis has underlined that the cross-border transmission of shocks can be rapid and powerful in the EMU, where trade and financial inter-linkages are strong and where confidence effects have been shown to be an important transmission mechanism. In particular, sovereign markets have been identified as powerful vectors of contagion during the crisis; therefore, a good understanding of cross-border spillovers within the euro area is essential for policy coordination and design.

In this paper we have used a measure recently proposed by Diebold and Yilmaz (2012) to assess the volatility spillovers in EMU sovereign bond markets during the period April 1999 to January 2014. To gain further insight into the recent state of financial instability in these markets, we have examined both central (Austria, Belgium, Finland, France, Germany and the Netherlands) and peripheral EMU countries (Greece, Ireland, Italy, Portugal and Spain).

For the whole sample, we have obtained a value of $54.23 \%$ for the total volatility spillover index among the eleven countries under study. Italy and Spain are the main net transmitters of bond yields shocks to other countries, while Portugal and Ireland are found to be the leading net receivers. As for the dynamics of the total volatility spillovers, we have identified a first period (denoted the "pre-crisis period") during which bond yield volatility was substantially transmitted to others, and a second one (denoted the "crisis period") during which the spillover of bond yield volatility registered a decrease. April 62009 was the breakpoint.

When analysing net pair-wise directional spillovers, our results suggest a radical change in their pattern, both in intensity and in direction, after April 2009: during the pre-crisis 
period most of the triggers in the volatility spillovers are central countries while during the crisis period peripheral countries become $\mathrm{t}$

he dominant transmitters. Additionally, the number of connections in volatility among EMU bond markets dramatically increased after the crisis, suggesting a higher cross-market exposure.

Finally, we have found that the key determinants in the central and peripheral countries are not the same. Although, in both cases, four variables assessing macroeconomic fundamentals are significant with the expected sign (the government debt-to-GDP, the current account-to-GDP and the inflation rate in the two group of countries, jointly with the measure of market liquidity and the government deficit-to-GDP, in central and peripheral countries, respectively); only one variable measuring market sentiment (the consumer confidence indicator, CCI) is statistically significant to explain spillovers between central countries, while two variables (EVOL and CCI) are significant with the expected sign in the case of peripheral countries. Therefore, these results suggest that variables that gauge market participants' perceptions seem to be more relevant in net volatility spillovers between peripheral countries, whilst macroeconomic fundamentals seem to play a major role in relationships where only central countries are involved. Nevertheless, it is also noticeable that the variables that gauge fiscal distress are more relevant in peripheral countries.

However, in the case of those relationships that run from a central to a peripheral country, or vice versa, both types of variable seem to be equally relevant. Finally, without exception, all marginal effects register an increase in the crisis period compared to the pre-crisis period, suggesting that the market participants reassess the relevance of the variables as the crisis unfolds. 
All in all, our results give further support to the hypothesis that, during the first ten years of EMU, peripheral countries imported credibility from central countries. With the outbreak of the crisis, there was a sudden shift in the sentiment of market participants, who suddenly turned their attention to the significant macroeconomic imbalances in some of the peripheral countries and the possibility of contagion to central countries.

The findings of this paper may increase further our understanding of the level and transmission mechanism of volatility spillovers across EMU sovereign bond markets, drawing attention to the intricate and time-variant linkages that exist between such markets. They may be of use to market regulators in their attempts to formulate effective policies for tackling financial uncertainty and tension transmission, particularly during periods of turbulence. 
Appendix A: Definition of the explanatory variables for modelling net pairwise directional volatility spillovers

A.1. Variables that measure macro-fundamentals.

\begin{tabular}{|c|c|c|}
\hline Variable & Description & Source \\
\hline $\begin{array}{c}\text { Net position } \\
\text { vis-à-vis } \\
\text { the rest of the } \\
\text { world } \\
\text { (CAC) }\end{array}$ & $\begin{array}{r}\text { Current-account-balance-to-GDP } \\
\text { Monthly data are linearly interpolated from } \\
\text { quarterly observations. }\end{array}$ & OECD \\
\hline $\begin{array}{c}\text { Competitiveness } \\
\text { (INF) }\end{array}$ & $\begin{array}{c}\text { Inflation rate. HICP monthly inter-annual rate } \\
\text { of growth }\end{array}$ & Eurostat \\
\hline $\begin{array}{c}\text { Fiscal Position } \\
\text { (DEF and DEB) }\end{array}$ & $\begin{array}{c}\text { Government debt-to-GDP and Government } \\
\text { deficit-to-GDP. Monthly data are linearly } \\
\text { interpolated from quarterly observations. }\end{array}$ \\
\hline $\begin{array}{c}\text { Market liquidity } \\
\text { (LIQ) }\end{array}$ & $\begin{array}{c}\text { Amounts Outstanding (billions of US dollars) } \\
\text { Monthly data are linearly interpolated from } \\
\text { quarterly observations. }\end{array}$ & BIS Debt securities statistics. \\
\end{tabular}

A.2. Variables used as proxies of investor behaviour.

\begin{tabular}{|c|c|c|}
\hline $\begin{array}{c}\text { Stock Volatility } \\
\text { (EVOL) }\end{array}$ & $\begin{array}{c}\text { Donthly standard deviation of the daily } \\
\text { returns of each country's stock market } \\
\text { general index }\end{array}$ & Datastream \\
\hline $\begin{array}{c}\text { Consumer } \\
\text { Confidence } \\
\text { Indicator } \\
(\mathrm{CCI})\end{array}$ & $\begin{array}{c}\text { This index is built up by the European } \\
\text { Commission which conducts regular } \\
\text { harmonised surveys of consumers in each } \\
\text { country }\end{array}$ & $\begin{array}{c}\text { European Commission (DG } \\
\text { ECFIN) }\end{array}$ \\
\hline
\end{tabular}

\section{Acknowledgements}

The authors thank the editor and two anonymous referees for useful comments and suggestions on a previous draft of this article, substantially improving the content and quality of the article. The authors are also very grateful to Maria del Carmen RamosHerrera and Manish K. Singh for excellent research assistance. This paper is based upon work supported by the Government of Spain and FEDER under grant numbers ECO2011-23189 and ECO2013-48326. Simón Sosvilla-Rivero thanks the Universitat de Barcelona and RFA-IREA for their hospitality. Responsibility for any remaining errors rests with the authors. 


\section{References}

Alter, A., \& Beyer, A. (2014). The dynamics of spillover effects during the European sovereign debt turmoil. Journal of Banking and Finance, 42, 134-152.

Antonakakis, N., \& Vergos, K. (2013). Sovereign bond yield spillovers in the Euro zone during the financial and debt crisis. Journal of International Financial Markets, Institutions and Money, 26, $258-272$

Apostolakisa, G., \& Papadopoulos, A. P. (2014). Financial stress spillovers in advanced economies. Journal of International Financial Markets, Institutions and Money, 32, 128-149

Awartania, B., Maghyerehb, A.I., \& Al Shiabc, M. (2013). Directional spillovers from the U.S. and the Saudi market to equities in the Gulf Cooperation Council countries. Journal of International Financial Markets, Institutions and Money, 27, 224-242.

Barnes, S., Lane, P. R., \& Radziwill,. A. (2010). Minimising risks from imbalances in European banking. Working Paper 828, Economics Department, Organization for Economic Cooperation and Development, Paris.

Beirne, J., \& Fratzscher, M. (2013). The pricing of sovereign risk and contagion during the European sovereign debt crisis. Journal of International Money and Finance, 34, 60-82.

Billio, M., Getmansky, M. Lo, A.W., \& Pelizzon, L. (2012). Econometric measures of connectedness and systemic risk in the finance and insurance sectors. Journal of Financial Economics, 104, 535-559.

Breusch, T. S., \& Pagan, A R. (1980). The Lagrange multiplier test and its applications to model specification in econometrics. Review of Economic Studies, 47, 239-253.

Caporin, M., Pelizzon, L., Ravazzolo, F., \& Rigobon, R. (2013). Measuring sovereign contagion in Europe. Working Paper 18741, National Bureau of Economic Research, Cambridge, MA.

Chakrabarti, A. \& Zeaiter, H. (2014). The determinants of sovereign default: A sensitivity analysis

International Review of Economics and Finance, 33, 300-318.

Chau, F., \& Deesomsak, R. (2014). Does linkage fuel the fire? The transmission of financial stress across the markets. International Review of Financial Analysis, 36, 57-70.

Claeys, P., \& Vašicek, B. (2014). Measuring bilateral spillover and testing contagion on sovereign bond markets in Europe. Journal of Banking and Finance, 46, 151-165.

Constâncio, V. (2012). Contagion and the European debt crisis. Financial Stability Review, 16, 109119.

Cronin, D. (2014). The interaction between money and asset markets: A spillover index approach. Journal of Macroeconomics, 39, 185-202.

Diebold, F. X., \& Yilmaz, K. (2012). Better to give than to receive: Predictive directional measurement of volatility spillovers. International Journal of Forecasting, 28, 57-66.

Dornbusch, R., Park, Y.C., \& Claessens, S. (2000). Contagion: understanding how it spreads. The World Bank Research Observer, 15, 177-198.

Duncan, A. S., \& Kabundi, A. (2013). Domestic and foreign sources of volatility spillover to South African asset classes. Economic Modelling, 31, 566-573.

European Commission (1995). The impact of exchange-rate movements on trade within the single market. European Economy, 4, 1-94.

Goldstein, M. (1998). The Asian Crisis: Causes, Cures, and Systemic Implications. Washington, DC: Institute for International Economics.

Gómez-Puig, M. (2006). Size matters for liquidity: Evidence from EMU sovereign yield spreads. Economics Letters, 90, 156-162.

Gómez-Puig, M. (2008). Monetary integration and the cost of borrowing. Journal of International Money and Finance, 27, 455-479. 
Gómez-Puig, M., \& Sosvilla-Rivero, S. (2013). Granger-causality in peripheral EMU public debt markets: A dynamic Approach. Journal of Banking and Finance, 37, 4627-4649.

Gómez-Puig, M., \& Sosvilla-Rivero, S. (2014). Causality and contagion in EMU sovereign debt markets. International Review of Economics and Finance, 33, 12-27.

Gómez-Puig, M., Sosvilla-Rivero, S., \& Ramos-Herrera, M.C. (2014). An update on EMU sovereign yield spreads drivers in times of crisis: A panel data analysis. The North American Journal of Economics and Finance, 30, 133-153.

Gorea, D., \& Radev, D. (2014). The euro area sovereign debt crisis: Can contagion spread from the periphery to the core? International Review of Economics and Finance, 30, 78-100.

Glover, B., \& Richards-Shubik, S. (2014). Contagion in the European Sovereign Debt Crisis. Working Paper No. 20567, National Bureau of Economic Research, Cambridge, MA.

Hendry, D.F. (1995). Dynamic Econometrics. Oxford: Oxford University Press.

Inoue, A., Jin, L. \& Rossi, B. (2014). Window selection for out-of-sample forecasting with timevarying parameters. Discussion Paper 10168, Centre for Economic Policy Research, London.

Jacquemin, A. \& Sapir, A. (1996). Is a European hard core credible? A statistical analysis. Kyklos, 49, 105-117.

Kalbaska, A., \& Gatkowski, M. (2012). Eurozone sovereign contagion: Evidence from the CDS market (2005-2010). Journal of Economic Behaviour and Organization, 83, 657-673.

Kalemi-Ozcan, S.; Papaioannou, E., \& Peydró-Alcalde, J. L. (2010). What lies beneath the Euro's effect on financial integration? Currency risk, legal harmonization, or trade? Journal of International Economics, 81, 75-88.

Koop, G., Pesaran, M. H., \& Potter, S. M. (1996). Impulse response analysis in nonlinear multivariate models. Journal of Econometrics, 74, 119-147.

Ledesma-Rodríguez, F., Navarro-Ibáñez, M, Pérez-Rodríguez, J. \& Sosvilla-Rivero, S. (2005). Assessing the credibility of a target zone: Evidence from the EMS. Applied Economics, 37, 22652287.

Lee, H. C. \& Chang, S. L. (2013). Finance Spillovers of currency carry trade returns, market risk sentiment, and U.S. market returns. The North American Journal of Economics and Finance, 26, 197-216.

Ludwig, A. (2014). A unified approach to investigate pure and wake-up-call contagion: Evidence from the Eurozone's first financial crisis. Journal of International Money and Finance, 48, 125-146.

Metieu, N. (2012). Sovereign risk contagion in the Eurozone. Economics Letters, 117, 35-38.

Narayan, P. K., Narayan, S., \& Prabheesh K. P. (2014). Stock returns, mutual fund flows and spillover shocks. Pacific-Basin Finance Journal, 29, 146-162.

Parkinson, M. (1980). The extreme value method for estimating the variance of the rate of return. Journal of Business, 53, 61-65.

Pesaran, H. H., \& Shin, Y. (1998) Generalized impulse response analysis in linear multivariate models. Economics Letters, 58, 17-29.

Schoenmaker, D., \& Wagner, W. (2013). Cross-border banking in Europe and financial stability, International Finance, 16, 1-22

Sosvilla-Rivero, S. \& Morales-Zumaquero, A. (2012). Volatility in EMU sovereign bond yields: Permanent and transitory components. Applied Financial Economics, 22, 1453-1464.

Suh, S. (2015). Measuring sovereign risk contagion in the Eurozone, International Review of Economics and Finance, 35, 45-65.

Tsai, I. C. (2014). Spillover of fear: Evidence from the stock markets of five developed countries, International Review of Financial Analysis, 33, 281-288.

White, H. (1980). A heteroskedasticity-consistent covariance matrix estimator and a direct test for heteroskedasticity, Econometrica, 48, 817-838 
Yilmaz, K. (2010). Return and volatility spillovers among the East Asian equity markets. Journal of Asian Economics, 21, 304-313.

Zhou, X., Zhang, W., \& Zhang, J. (2012). Volatility spillovers between the Chinese and world equity markets. Pacific-Basin Finance Journal, 20, 247-270. 
Table 1: Full-sample spillovers

\begin{tabular}{|c|c|c|c|c|c|c|c|c|c|c|c|c|}
\hline & GER & FRA & ITA & SPA & NET & BEL & AUS & GRE & FIN & POR & IRE & Contributions from others \\
\hline GER & 20.05 & 18.39 & 2.83 & 1.34 & 17.09 & 9.79 & 13.04 & 0.08 & 17.20 & 0.07 & 0.12 & 79.95 \\
\hline FRA & 10.38 & 29.44 & 1.10 & 0.29 & 14.93 & 13.11 & 15.48 & 0.41 & 14.71 & 0.09 & 0.07 & 70.56 \\
\hline SPA & 0.22 & 0.03 & 34.03 & 61.69 & 0.20 & 1.69 & 0.08 & 0.08 & 0.34 & 0.38 & 1.26 & 38.31 \\
\hline NET & 12.24 & 18.85 & 2.74 & 0.50 & 20.64 & 12.72 & 14.75 & 0.01 & 17.38 & 0.16 & 0.02 & 79.36 \\
\hline AUS & 9.13 & 20.03 & 1.06 & 0.19 & 15.11 & 14.00 & 23.83 & 0.55 & 15.93 & 0.16 & 0.01 & 76.17 \\
\hline GRE & 0.10 & 0.23 & 2.89 & 2.13 & 0.10 & 0.12 & 0.01 & 92.66 & 0.03 & 1.05 & 0.67 & 7.34 \\
\hline FIN & 12.09 & 18.65 & 3.23 & 1.04 & 17.09 & 11.55 & 15.74 & 0.10 & 20.39 & 0.09 & 0.03 & 79.61 \\
\hline POR & 0.01 & 0.37 & 10.13 & 13.34 & 0.04 & 0.04 & 0.36 & 10.44 & 0.04 & 54.45 & 10.80 & 45.55 \\
\hline IRE & 0.07 & 0.36 & 8.28 & 10.23 & 0.00 & 1.02 & 0.12 & 2.70 & 0.01 & 6.04 & 71.18 & 28.82 \\
\hline $\begin{array}{c}\text { Contributions to } \\
\text { Others }\end{array}$ & 71.23 & 74.83 & 53.63 & 48.99 & 78.24 & 62.02 & 74.15 & 13.69 & 78.58 & 13.17 & 16.48 & Index $=54.23 \%$ \\
\hline $\begin{array}{c}\text { Net } \\
\text { contributions } \\
\text { (To-From) }\end{array}$ & -8.72 & 4.27 & 21.63 & 10.68 & -1.12 & 3.13 & -2.02 & 6.34 & -1.03 & -32.37 & -12.34 & \\
\hline
\end{tabular}

Note: GER, FRA, ITA, SPA, NET, BEL AUS, GRE, FIN, POR and IRE stand for Germany, France, Italy, Spain, the Netherlands, Belgium, Austria, Greece, Finland, Portugal and Ireland, respectively. 
Table 2. Panel regression: All countries

\begin{tabular}{|c|c|c|}
\hline & Without dummy & With dummy \\
\hline \multirow[t]{2}{*}{ Constant } & $\begin{array}{l}-1.2917^{*} \\
(-13.7264)\end{array}$ & $\begin{array}{l}-1.1600^{*} \\
(-2.5681)\end{array}$ \\
\hline & & $\begin{array}{l}-3.0225^{*} \\
(-17.4723)\end{array}$ \\
\hline \multicolumn{3}{|l|}{ Fundamental variables } \\
\hline \multirow[t]{2}{*}{ Inflation Rate } & $\begin{array}{l}-0.7573^{*} \\
(-20.6019)\end{array}$ & $\begin{array}{l}-0.5181^{*} \\
(-10.7612)\end{array}$ \\
\hline & & $\begin{array}{c}-.0202^{*} \\
(-27.9214)\end{array}$ \\
\hline \multirow[t]{2}{*}{ Gov. Debt / GDP } & $\begin{array}{l}-0.1150^{*} \\
(-14.7865)\end{array}$ & $\begin{array}{c}-0.1069^{*} \\
(-14.1385)\end{array}$ \\
\hline & & $\begin{array}{l}-0.0910^{*} \\
(-13.0871)\end{array}$ \\
\hline \multicolumn{3}{|c|}{ Proxies of investor behaviour } \\
\hline \multirow[t]{2}{*}{$\begin{array}{l}\text { Consumer Confidence } \\
\text { Indicator }\end{array}$} & $\begin{array}{c}0.5014 * \\
(12.1598)\end{array}$ & $\begin{array}{l}0.4044 * \\
(9.2736)\end{array}$ \\
\hline & & $\begin{array}{c}0.3381 * \\
(28.0223)\end{array}$ \\
\hline \multirow[t]{2}{*}{ Equity Volatility } & $\begin{array}{l}-0.0120^{*} \\
(-19.9724)\end{array}$ & $\begin{array}{l}-0.0087^{*} \\
(-16.2926)\end{array}$ \\
\hline & & $\begin{array}{l}-0.0119^{*} \\
(-14.3343) \\
\end{array}$ \\
\hline $\mathrm{R}^{2}$ & & \\
\hline Within & 0.4176 & 0.4640 \\
\hline Between & 0.6703 & 0.7448 \\
\hline Overall & 0.4732 & 0.5205 \\
\hline
\end{tabular}

Notes: In brackets below the parameter estimates are the corresponding z-statistics, computed using White (1980)'s heteroskedasticity-robust standard errors. $*$ indicates significance at $1 \%$. 
Table 3. Panel regression: Central-Central countries

\begin{tabular}{|c|c|c|}
\hline & Without dummy & With dummy \\
\hline Constant & $\begin{array}{l}-0.2260 * \\
(-2.1684)\end{array}$ & \\
\hline \multicolumn{3}{|l|}{ Fundamental variables } \\
\hline \multirow[t]{2}{*}{ Inflation Rate } & $\begin{array}{c}-1.4425^{*} \\
(-14.5449) \\
\end{array}$ & $\begin{array}{l}-1.1273^{*} \\
(5.3212) \\
\end{array}$ \\
\hline & & $\begin{array}{l}-0.3986^{*} \\
(3.7390)\end{array}$ \\
\hline \multirow[t]{2}{*}{ Gov. Debt / GDP } & $\begin{array}{c}-0.3960^{*} \\
(-18.4229)\end{array}$ & $\begin{array}{l}-0.2327^{*} \\
(-10.0917)\end{array}$ \\
\hline & & $\begin{array}{l}-0.2209^{*} \\
(-15.6501)\end{array}$ \\
\hline \multirow[t]{2}{*}{ Current Account / GDP } & $\begin{array}{c}0.3207^{*} \\
(10.6660) \\
\end{array}$ & $\begin{array}{c}0.3358^{*} \\
(10.1612) \\
\end{array}$ \\
\hline & & $\begin{array}{l}0.0071 * \\
(6.6614)\end{array}$ \\
\hline \multirow[t]{2}{*}{$\begin{array}{l}\text { Liquidity-Domestic Debt } \\
\text { Securities }\end{array}$} & $\begin{array}{c}0.0060^{*} \\
(11.7735) \\
\end{array}$ & $\begin{array}{l}0.0054^{*} \\
(7.4833)\end{array}$ \\
\hline & & $\begin{array}{c}0.0048^{*} \\
(12.6223)\end{array}$ \\
\hline \multicolumn{3}{|c|}{ Proxies of investor behaviour } \\
\hline $\begin{array}{l}\text { Consumer Confidence } \\
\text { Indicator }\end{array}$ & $\begin{array}{c}0.1817^{*} \\
(11.5893) \\
\end{array}$ & $\begin{array}{c}0.2219^{*} \\
(11.7614)\end{array}$ \\
\hline & & $\begin{array}{c}0.0248^{*} \\
(12.6255)\end{array}$ \\
\hline $\begin{array}{l}\mathrm{R}^{2} \\
\text { Within } \\
\text { Between } \\
\text { Overall }\end{array}$ & $\begin{array}{l}0.4594 \\
0.7038 \\
0.4969\end{array}$ & $\begin{array}{l}0.4824 \\
0.7390 \\
0.5466\end{array}$ \\
\hline
\end{tabular}

Notes: In brackets below the parameter estimates are the corresponding ₹-statistics, computed using White (1980)'s heteroskedasticity-robust standard errors. $*$ indicates significance at $1 \%$. 
Table 4. Panel regression: Peripheral-Peripheral countries

\begin{tabular}{|c|c|c|}
\hline & Without dummy & With dummy \\
\hline \multirow[t]{2}{*}{ Constant } & $\begin{array}{l}-1.4944^{*} \\
(-5.7866)\end{array}$ & $\begin{array}{l}-1.7160^{*} \\
(-6.8014)\end{array}$ \\
\hline & & $\begin{array}{l}-0.4054 * \\
(-9.3624) \\
\end{array}$ \\
\hline \multicolumn{3}{|l|}{ Fundamental variables } \\
\hline \multirow[t]{2}{*}{ Inflation Rate } & $\begin{array}{c}-2.4872^{*} \\
(-11.3238) \\
\end{array}$ & $\begin{array}{l}-2.1864^{*} \\
(-10.4642) \\
\end{array}$ \\
\hline & & $\begin{array}{l}-0.3729 * \\
(-5.0861) \\
\end{array}$ \\
\hline \multirow[t]{2}{*}{ Gov. Deficit / GDP } & $\begin{array}{l}-0.2836 * \\
(-6.1688)\end{array}$ & $\begin{array}{l}-0.1055^{*} \\
(-6.8612)\end{array}$ \\
\hline & & $\begin{array}{c}-0.2988^{*} \\
(-11.9701) \\
\end{array}$ \\
\hline \multirow[t]{2}{*}{ Gov. Debt / GDP } & $\begin{array}{l}-0.1815^{*} \\
(-9.6749)\end{array}$ & $\begin{array}{l}-0.1918^{*} \\
(-8.5503) \\
\end{array}$ \\
\hline & & $\begin{array}{l}-0.0088^{*} \\
(-3.7342) \\
\end{array}$ \\
\hline \multirow[t]{2}{*}{ Current Account / GDP } & $\begin{array}{l}0.6175^{*} \\
(5.1249)\end{array}$ & $\begin{array}{l}0.8223^{*} \\
(6.5712)\end{array}$ \\
\hline & & $\begin{array}{l}0.0874^{*} \\
(5.8425)\end{array}$ \\
\hline \multicolumn{3}{|c|}{ Proxies of investor behaviour } \\
\hline \multirow[t]{2}{*}{$\begin{array}{l}\text { Consumer Confidence } \\
\text { Indicator }\end{array}$} & $\begin{array}{c}1.0213^{*} \\
(37.0696)\end{array}$ & $\begin{array}{l}1.0984^{*} \\
(5.8021)\end{array}$ \\
\hline & & $\begin{array}{c}0.0861^{*} \\
(21.3315)\end{array}$ \\
\hline \multirow[t]{2}{*}{ Equity Volatility } & $\begin{array}{l}-0.0052 * \\
(-4.4438)\end{array}$ & $\begin{array}{l}-0.0058^{*} \\
(-8.0632)\end{array}$ \\
\hline & & $\begin{array}{l}-0.0205^{*} \\
(-8.8014)\end{array}$ \\
\hline $\begin{array}{l}\mathrm{R}^{2} \\
\text { Within } \\
\text { Between } \\
\text { Overall }\end{array}$ & $\begin{array}{l}0.4532 \\
0.6972 \\
0.5659\end{array}$ & $\begin{array}{l}0.6004 \\
0.8193 \\
0.5728\end{array}$ \\
\hline Observations & & \\
\hline
\end{tabular}

Notes: In brackets below the parameter estimates are the corresponding ₹-statistics, computed using White (1980)'s heteroskedasticity-robust standard errors. * indicates significance at $1 \%$. 
Table 5. Panel regression: Central-Peripheral countries

\begin{tabular}{|c|c|c|}
\hline & Without dummy & With dummy \\
\hline Constant & $\begin{array}{l}-1.6110^{*} \\
(-12.9196)\end{array}$ & $\begin{array}{l}-1.8591 * \\
(10.4412)\end{array}$ \\
\hline & & $\begin{array}{l}-0.3715^{*} \\
(-16.5224) \\
\end{array}$ \\
\hline \multicolumn{3}{|l|}{ Fundamental variables } \\
\hline \multirow[t]{2}{*}{ Inflation Rate } & $\begin{array}{c}-0.9990^{*} \\
(-21.3251) \\
\end{array}$ & $\begin{array}{c}-0.9413^{*} \\
(-11.5631) \\
\end{array}$ \\
\hline & & $\begin{array}{l}-0.0759^{*} \\
(19.5406) \\
\end{array}$ \\
\hline \multirow[t]{2}{*}{ Gov. Debt / GDP } & $\begin{array}{c}-0.1223^{*} \\
(-11.9292)\end{array}$ & $\begin{array}{l}-0.1129 * \\
(-6.6621)\end{array}$ \\
\hline & & $\begin{array}{l}-0.0717 * \\
(-3.1447) \\
\end{array}$ \\
\hline \multirow[t]{2}{*}{$\begin{array}{l}\text { Liquidity-Domestic Debt } \\
\text { Securities }\end{array}$} & $\begin{array}{c}0.0047 \\
(9.5210)\end{array}$ & $\begin{array}{l}0.0042 * \\
(5.9219)\end{array}$ \\
\hline & & $\begin{array}{c}0.0054^{*} \\
(13.5775) \\
\end{array}$ \\
\hline \multicolumn{3}{|c|}{ Proxies of investor behaviour } \\
\hline \multirow[t]{2}{*}{$\begin{array}{l}\text { Consumer Confidence } \\
\text { Indicator }\end{array}$} & $\begin{array}{c}0.5041^{*} \\
(12.6214) \\
\end{array}$ & $\begin{array}{c}0.4101^{*} \\
(17.3314) \\
\end{array}$ \\
\hline & & $\begin{array}{c}0.1829^{*} \\
(26.1811) \\
\end{array}$ \\
\hline \multirow[t]{2}{*}{ Equity Volatility } & $\begin{array}{c}-0.0127^{*} \\
(-17.9196) \\
\end{array}$ & $\begin{array}{l}-00109^{*} \\
(-16.9412) \\
\end{array}$ \\
\hline & & $\begin{array}{l}-0.0031^{*} \\
(-11.1112) \\
\end{array}$ \\
\hline $\begin{array}{l}\mathrm{R}^{2} \\
\text { Within } \\
\text { Between } \\
\text { Overall }\end{array}$ & $\begin{array}{l}0.4235 \\
0.5856 \\
0.5656\end{array}$ & $\begin{array}{l}0.5748 \\
0.5650 \\
0.6199\end{array}$ \\
\hline
\end{tabular}

Notes: In brackets below the parameter estimates are the corresponding ₹-statistics, computed using White (1980)'s heteroskedasticity-robust standard errors. ${ }^{*}$ indicates significance at $1 \%$. 


\section{Figure 1: Total volatility spillover}

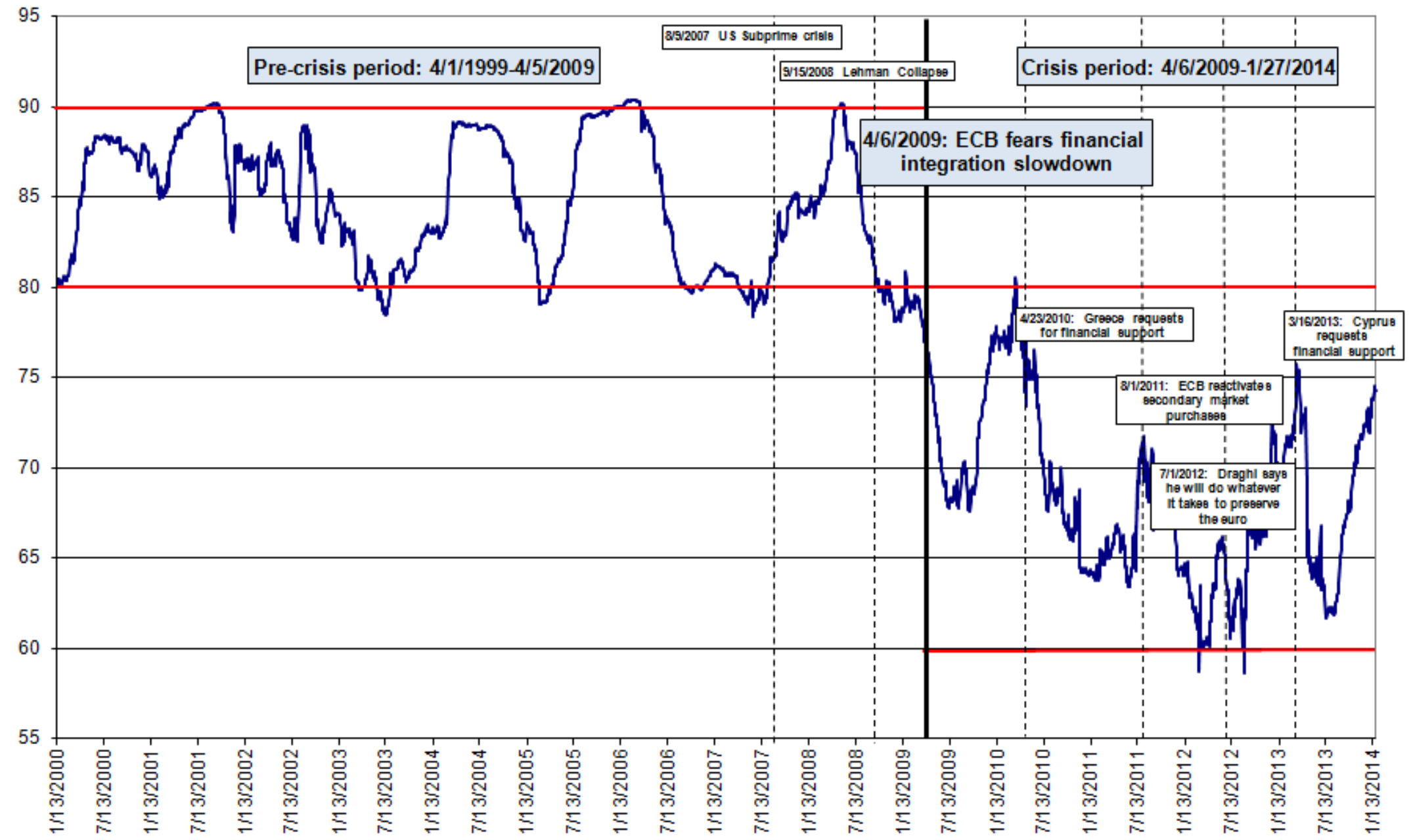


Figure 2a: Dynamic net pair-wise directional spillovers for the whole sample

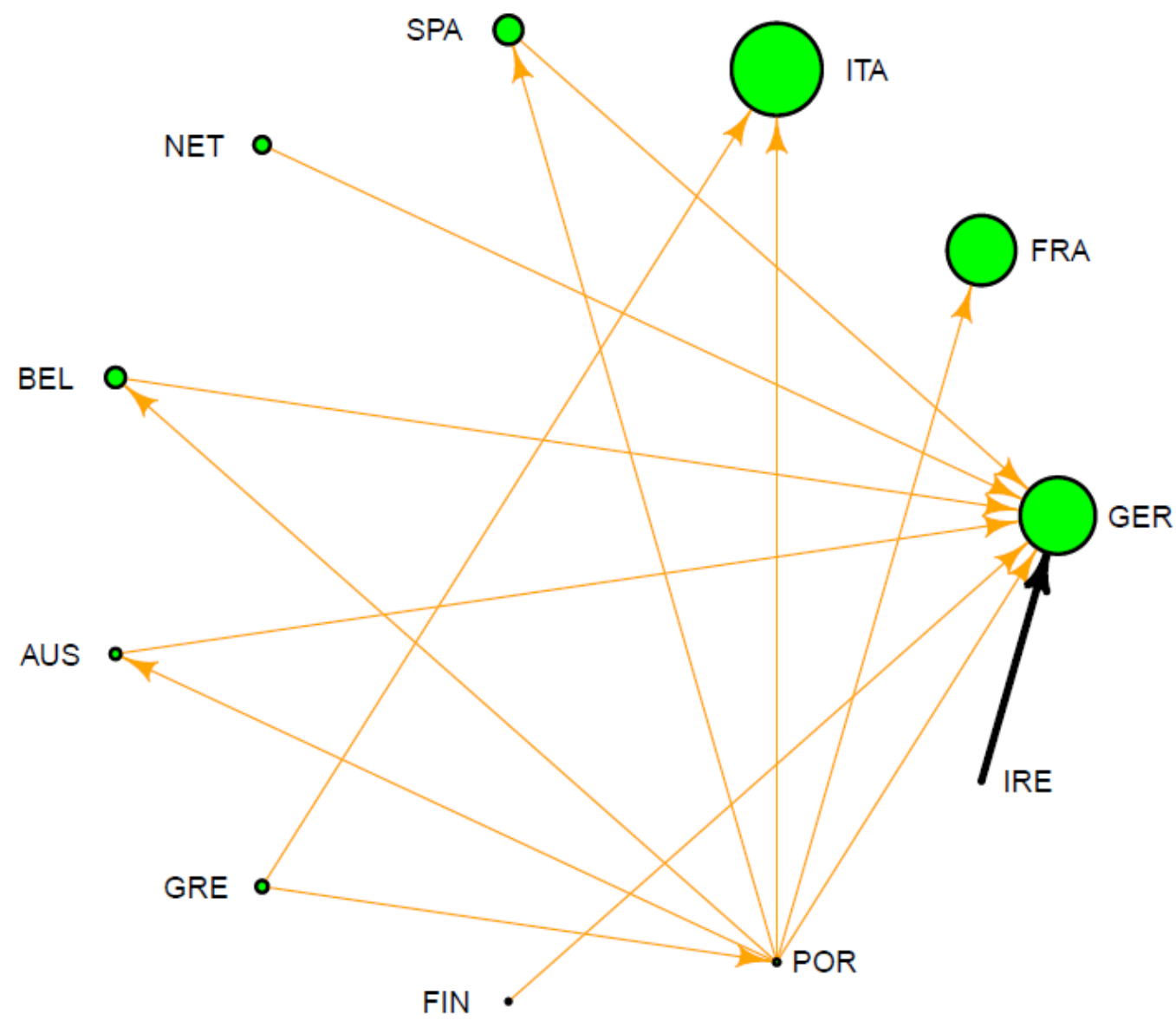

Notes: We show the most important directional connections between the 55 pairs of the 10 -year bond yields under study. Black, red and orange links (black, grey and light grey when viewed in grey scale) correspond, respectively, to the cases where we detect a net pair-wise directional connection in $64-75 \%, 76-87 \%$ and $88-100 \%$ of the sample. Node size indicates sovereign debt market size. GER, FRA, ITA, SPA, NET, BEL AUS, GRE, FIN, POR and IRE stand for Germany, France, Italy, Spain, the Netherlands, Belgium, Austria, Greece, Finland, Portugal and Ireland, respectively. 
Figure 2b: Dynamic net pair-wise directional spillovers for the pre-crisis period.

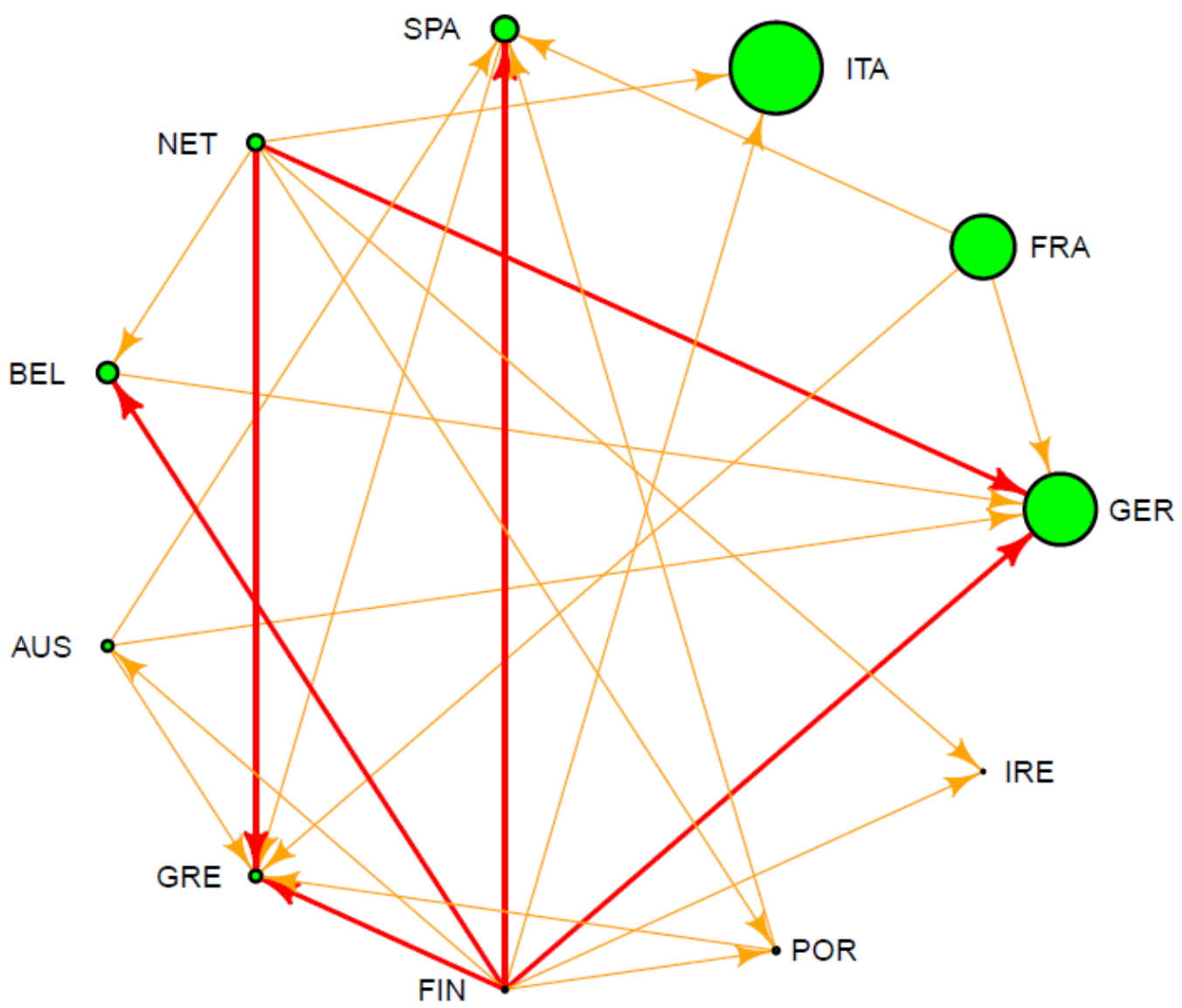

Notes: We show the most important directional connections between the 55 pairs of the 10 -year bond yields under study. Black, red and orange links (black, grey and light grey when viewed in grey scale) correspond, respectively, to the cases where we detect a net pair-wise directional connection in $64-75 \%, 76-87 \%$ and $88-100 \%$ of the sample. Node size indicates sovereign debt market size. GER, FRA, ITA, SPA, NET, BEL AUS, GRE, FIN, POR and IRE stand for Germany, France, Italy, Spain, the Netherlands, Belgium, Austria, Greece, Finland, Portugal and Ireland, respectively. 
Figure 2c: Dynamic net pair-wise directional spillovers for the crisis period.

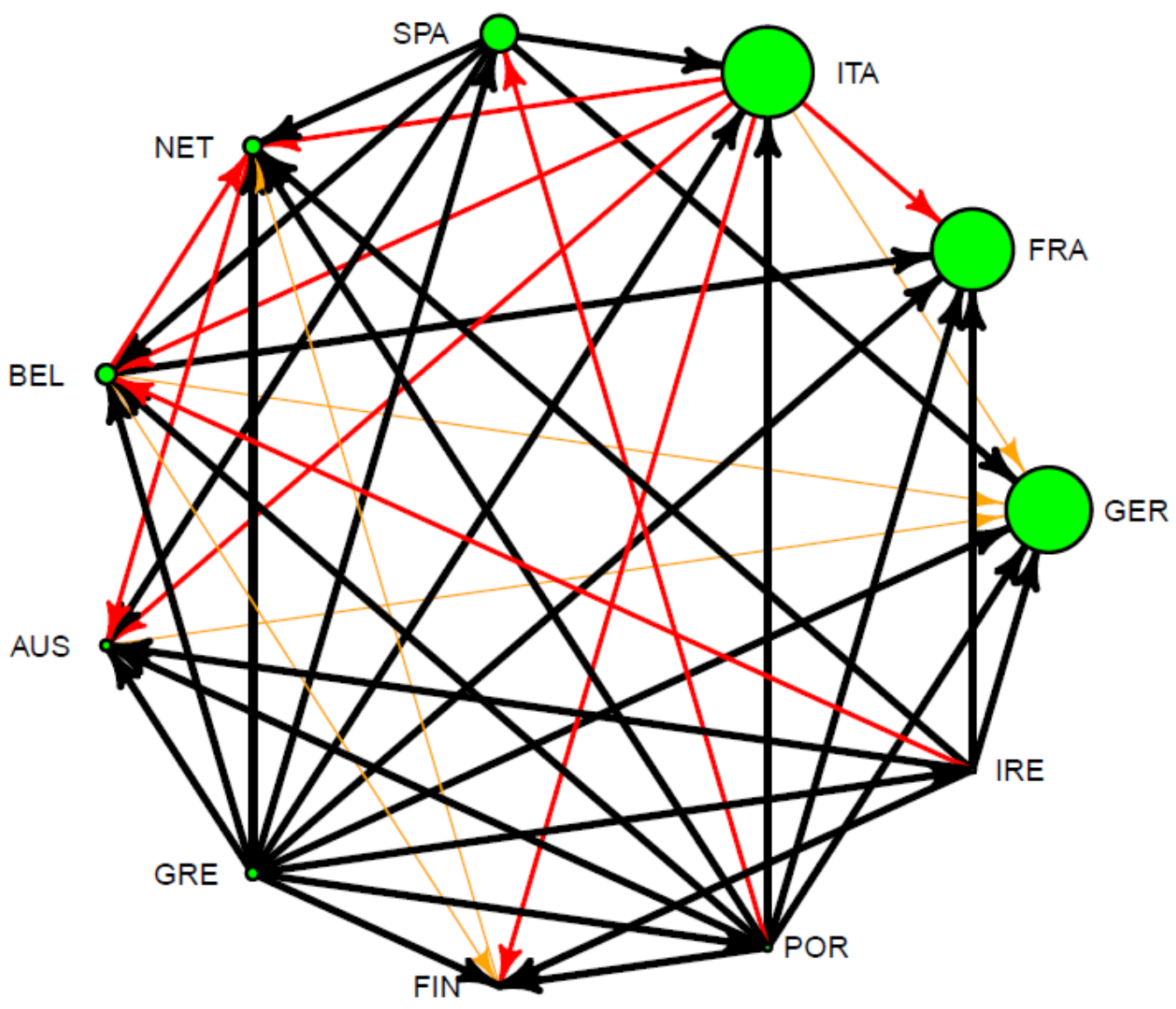

Notes: We show the most important directional connections between the 55 pairs of the 10 -year bond yields under study. Black, red and orange links (black, grey and light grey when viewed in grey scale) correspond, respectively, respectively, to the cases where we detect a net pair-wise directional connection in $64-75 \%, 76-87 \%$ and $88-100 \%$ of the sample Node size indicates sovereign debt market size. GER, FRA, ITA, SPA, NET, BEL AUS, GRE, FIN, POR and IRE stand for Germany, France, Italy, Spain, the Netherlands, Belgium, Austria, Greece, Finland, Portugal and Ireland, respectively. 
Figure 3a:

Main net spillovers in the pre-crisis period: From central to peripheral countries.

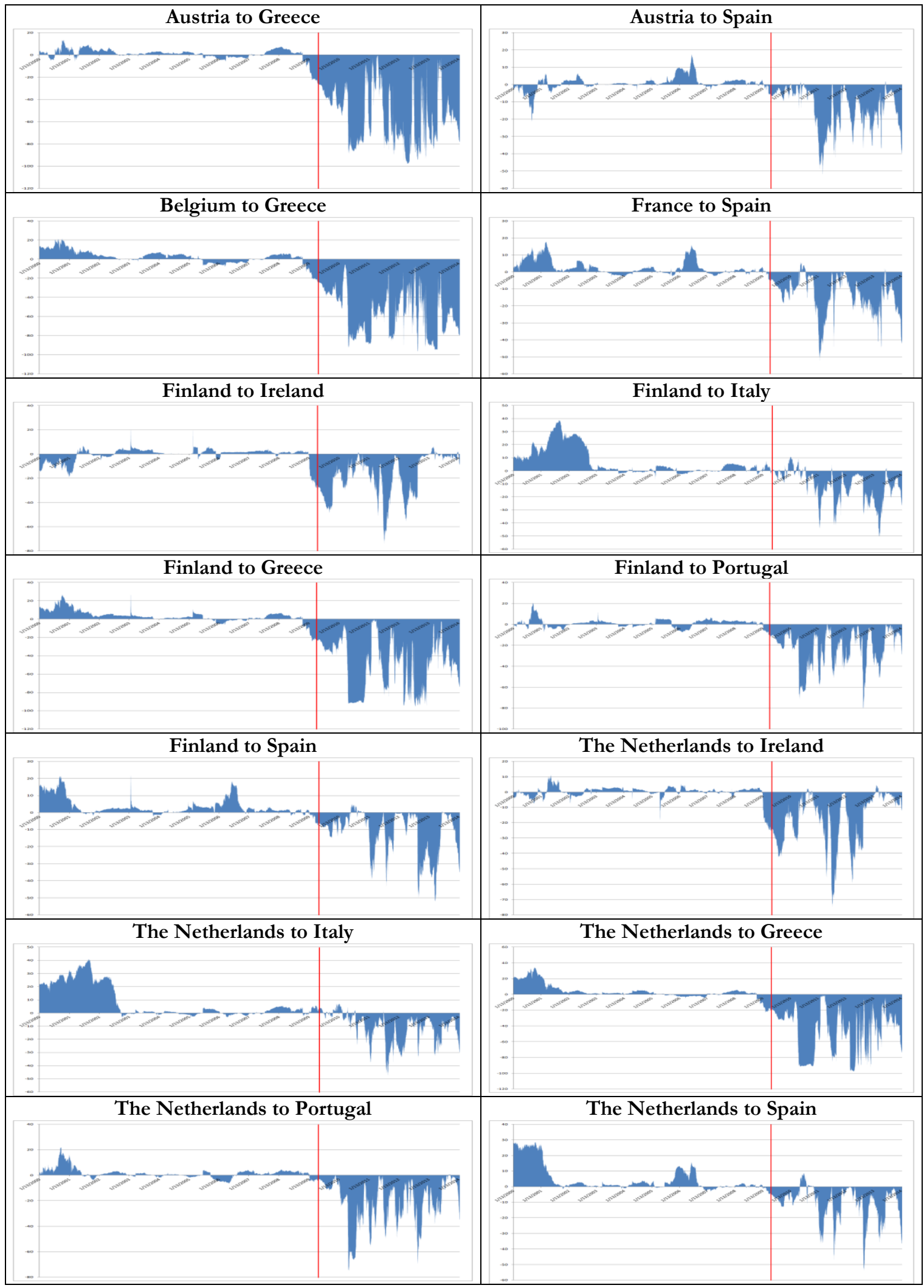


Figure 3b:

Main net spillovers in the crisis period: From peripheral to central countries.

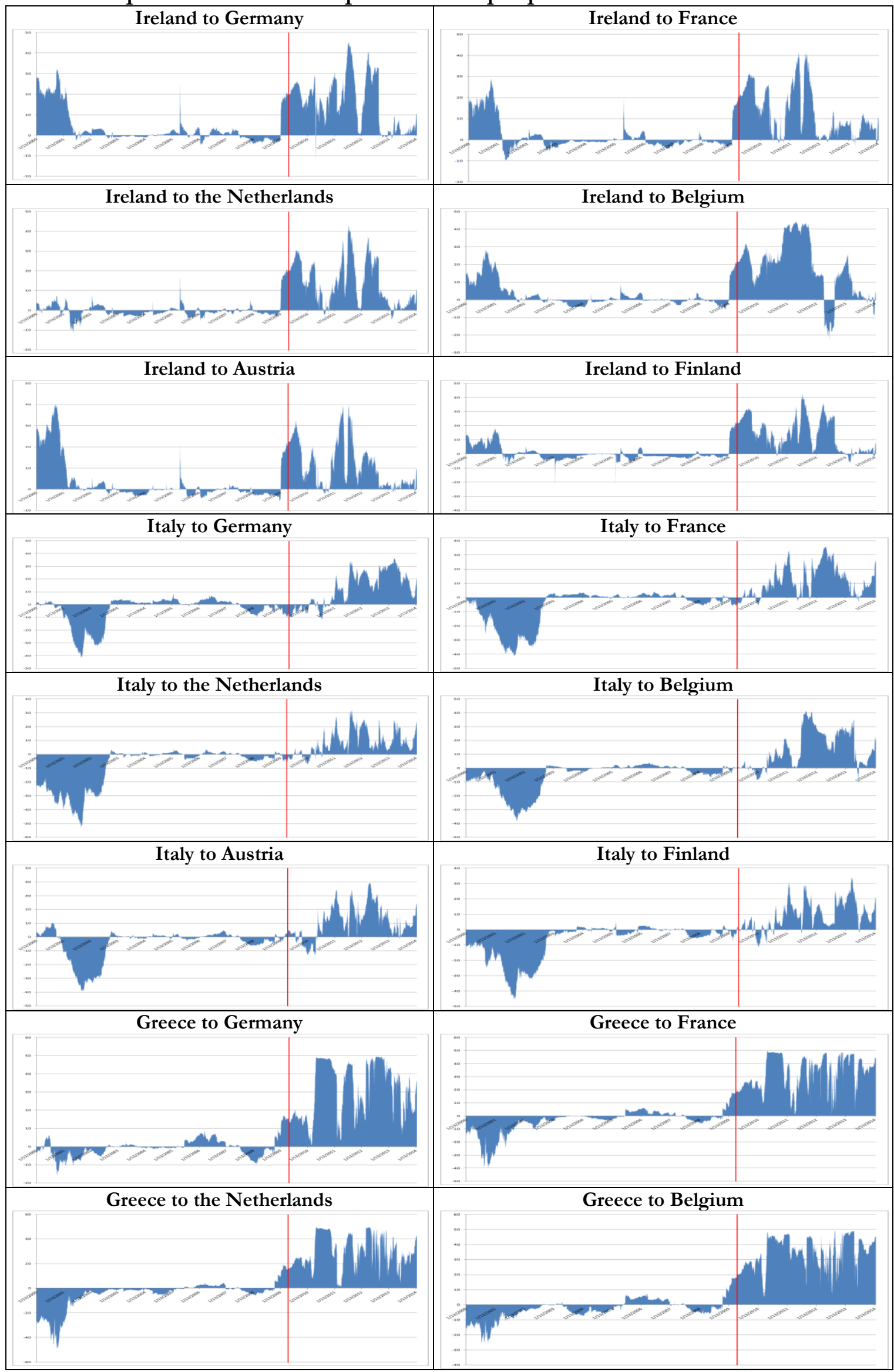




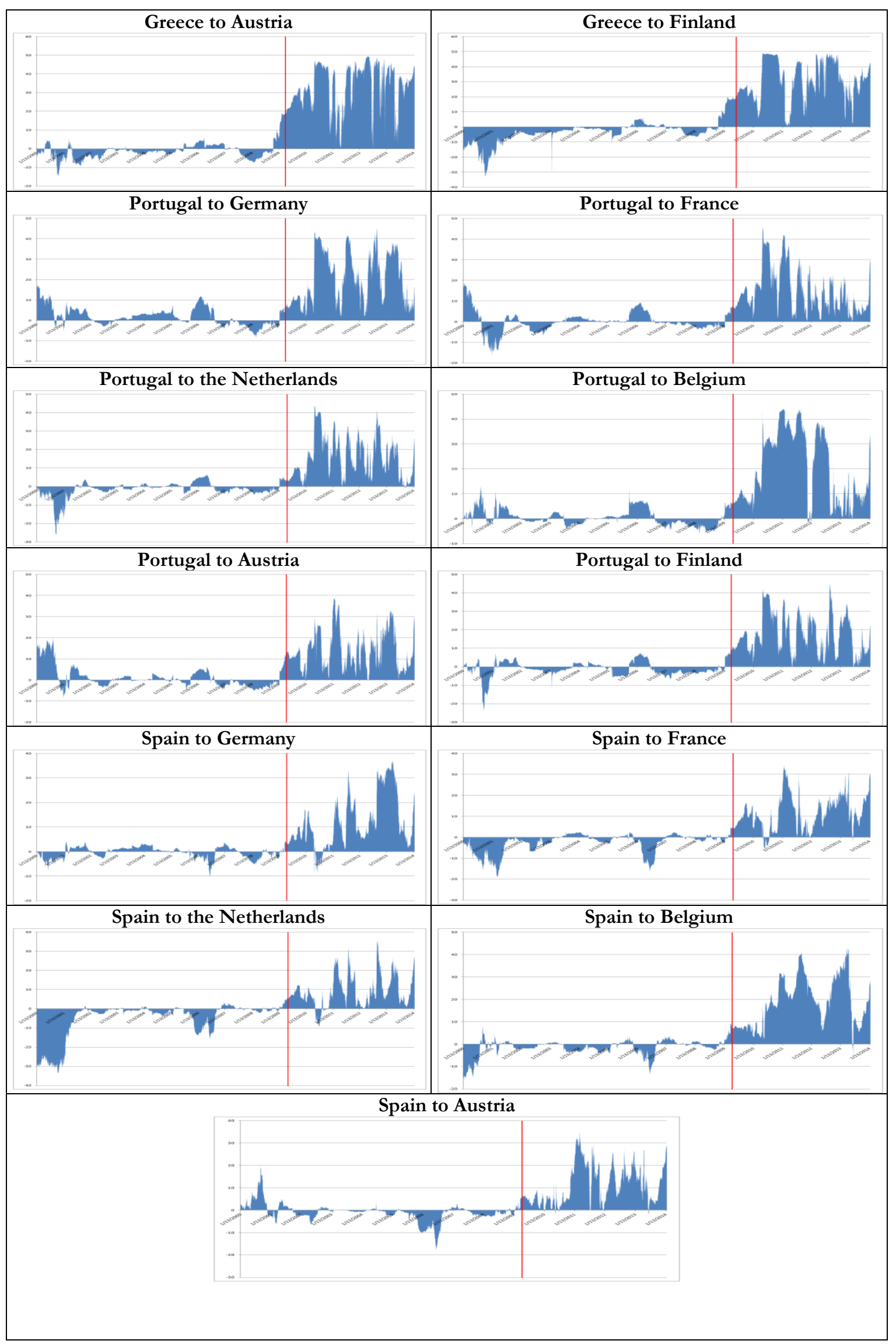

